Western University

Scholarship@Western

Aboriginal Policy Research Consortium International (APRCi)

2011

Silencing Aboriginal Curricular Content and Perspectives Through Multiculturalism: "There Are Other Children Here"

Verna St. Denis

Follow this and additional works at: https://ir.lib.uwo.ca/aprci

Part of the Curriculum and Instruction Commons

Citation of this paper:

St. Denis, Verna, "Silencing Aboriginal Curricular Content and Perspectives Through Multiculturalism: "There Are Other Children Here"" (2011). Aboriginal Policy Research Consortium International (APRCi). 268.

https://ir.lib.uwo.ca/aprci/268 
This article was downloaded by: [University of Western Ontario]

On: 25 October 2012, At: 13:23

Publisher: Routledge

Informa Ltd Registered in England and Wales Registered Number: 1072954

Registered office: Mortimer House, 37-41 Mortimer Street, London W1T 3J H, UK

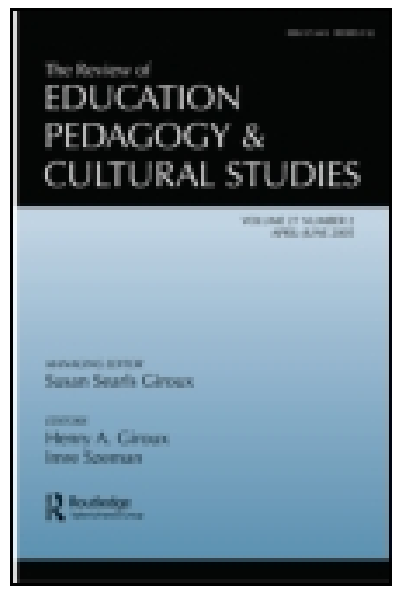

\section{Review of Education, Pedagogy, and Cultural Studies}

Publication details, including instructions for authors and subscription information:

http:// www. tandfonline.com/loi/gred20

\section{Silencing Aboriginal Curricular Content and Perspectives Through Multiculturalism: "There Are Other Children Here"}

Verna St. Denis

Version of record first published: 30 Aug 2011.

To cite this article: Verna St. Denis (2011): Silencing Aboriginal Curricular Content and Perspectives Through Multiculturalism: "There Are Other Children Here", Review of Education, Pedagogy, and Cultural Studies, 33:4, 306-317

To link to this article: http:// dx.doi.org/ 10.1080/ 10714413.2011.597638

PLEASE SCROLL DOWN FOR ARTICLE

Full terms and conditions of use: http://www.tandfonline.com/page/termsand-conditions

This article may be used for research, teaching, and private study purposes. Any substantial or systematic reproduction, redistribution, reselling, loan, sub-licensing, systematic supply, or distribution in any form to anyone is expressly forbidden.

The publisher does not give any warranty express or implied or make any representation that the contents will be complete or accurate or up to date. The accuracy of any instructions, formulae, and drug doses should be independently verified with primary sources. The publisher shall not be liable for any loss, actions, claims, proceedings, demand, or costs or damages 
whatsoever or howsoever caused arising directly or indirectly in connection with or arising out of the use of this material. 


\title{
Silencing Aboriginal Curricular Content and Perspectives Through Multiculturalism: "There Are Other Children Here"
}

\author{
Verna St. Denis
}

Recently I was invited to join a provincial discussion about the high school social science curriculum. One area of contention was whether all students should be required to take a course that would combine and integrate social studies, history, and native studies. Aware that integration of native studies content into existing courses could easily result in the erasure of native studies, I suggested, at that provincial meeting, that all students should take such a course if its starting point and continued foundation was native studies. One participant, in response to this suggestion, stated, "Aboriginal people are not the only people here."

This comment, "Aboriginal people are not the only people here," suggests that it would be wrong to privilege Aboriginal history, knowledge, and experience in the teaching of one high school course in Canadian history and social studies. This comment conveys a recurring sentiment that defends public education as a neutral multicultural space, but also effectively tempers Aboriginal educational initiatives. This article explores how multicultural discourses impact the reception of Aboriginal teachers, and the Aboriginal knowledge, history, and experience they bring into Canadian public schools. I argue that what happens to Aboriginal teachers in Canadian public schools as they attempt to include Aboriginal content and perspectives is a microcosm of what happens at the political and national levels in regard to Aboriginal peoples' 
claims to land and sovereignty in Canada. Some of the experiences of Aboriginal teachers in public schools help us to develop a deeper understanding of why Aboriginal political leaders reject having their rights negotiated within a multicultural framework.

I will begin this article with a brief discussion of multicultural policy and legislation in Canada. Then I will review some of the general criticisms of multiculturalism and, most importantly, some of the basic reasons Aboriginal people reject having their claims and rights framed within multiculturalism (see, e.g., Paine 1999; Day and Sadik 2002; Mackey 2002; Lawrence and Dua 2005; Mackey 2005; Short 2005; Rutherford 2010). The article then draws on data from two recent studies that have explored the experiences of Aboriginal teachers as they seek to include Aboriginal content and perspectives into public schools (St. Denis et al. 1998; St. Denis 2010). By inciting multiculturalism, public schools effectively limit meaningful incorporation of Aboriginal content and perspectives into public schools.

\section{MULTICULTURALISM IN CANADA}

In Canada, official multiculturalism was a political strategy that was introduced as a way to address contesting language, cultural, and land claims within the nation, and it has since been widely explained, defended, and critiqued (see, e.g., Fleras and Elliot 1992; Légaré 1995; Kymlicka 1996; Mackey 2002; Wood and Gilbert 2005). In 1971, then Prime Minister Trudeau institutionalized a policy of multiculturalism, and this policy was made into national law by the Mulroney government in 1988 as the Multicultural Act. ${ }^{1}$ The initial 1971 multicultural policy was an attempt to respond to the demands of French-language speakers, an increasing culturally diverse citizenry, and Aboriginal people. As has been observed, multiculturalism was "introduced so that bilingualism would not create extra problems" (Wood and Gilbert 2005, 682). The Multicultural Act of 1988 was intended to address the concerns of multiple ethnic groups, such as Ukrainians, who wanted recognition of their presence and contributions to Canada (Wood and Gilbert 2005). Multiculturalism was also intended to acknowledge the need for increased understanding between ethnic groups, and the need to address racial discrimination (Fleras and Elliot 1992, 75). Within the context of historical and ongoing colonization in 
Canada, both policies in fact prevent possibilities for anti-racism and anti-colonialism (Day 2000; Mackey 2002; Lawrence and Dua 2005).

Scholars have examined the shortcomings of multiculturalism (see, e.g., Povinelli 1998; Paine 1999; Curthoys 2000; Chakrabarty 2001; Day and Sadik 2002; Mackey 2002; Lawrence and Dua 2005; Mackey 2005; Short 2005; Wood and Gilbert 2005; Rutherford 2010; James 2011). First, multiculturalism encourages social division in that it "separates, intensifies misunderstanding and hostility, and pits one group against another in the competition for power and resources" (Fleras and Elliot 1992, 132). Next, multiculturalism is regressive because it is "derelict in combating social inequality" (Fleras and Elliot 1992, 134). Third, multiculturalism permits a form of participation on the part of those designated as "cultural others" that is limited to the decorative and includes "leisure, entertainment, food, and song and dance" (Fleras and Elliot 1992, 136). Finally, multiculturalism is "impractical" and "inadequate" for "sorting out the conflicting claims of individuals, minority groups, vested interests and a centralized state" (Fleras and Elliot 1992, 140). These four assertions begin to identify the ways in which multicultural policies and practices prevent an anti-colonial analysis.

In Canada, both Aboriginal people and racialized immigrants are concerned with the use of multicultural discourses to manage and silence competing interests within the nation. Although Aboriginal and racialized immigrants have similar concerns with multiculturalism, they also have very distinct ones. For example, racialized immigrants of color are concerned that multiculturalism does not address racism and anti-immigration sentiments but may even provoke them (Mackey 2002; James 2011). Aboriginal peoples are concerned with Indigenous sovereignty and asserting rights based on their original and continuing occupation of the land (Paine 1999; Day and Sadik 2002; Mackey 2002; Lawrence and Dua 2005; Mackey 2005; Short 2005; Rutherford 2010). In other words, Aboriginal groups suggest that multiculturalism is a form of colonialism and works to distract from the recognition and redress of Indigenous rights. Racism also impacts upon Aboriginal groups, and multiculturalism can justify public expressions of antiAboriginal sentiments. Discourses of multiculturalism enable racism and colonialism, and thereby impact and limit the work of Aboriginal teachers. 


\section{ABORIGINAL CRITIQUES OF MULTICULTURALISM}

A brief explanation of how Aboriginal people position themselves within Canada is helpful to understand why they reject multiculturalism as a framework to negotiate Aboriginal sovereignty. Aboriginal peoples continue to argue that they are Indigenous sovereign nations because of their original continuing occupation and rights to the land (Paine 1999; Day and Sadik 2002; Mackey 2002; Lawrence and Dua 2005; Mackey 2005; Short 2005; Rutherford 2010). Aboriginal groups explain "their rights are pre-contact, in place before the law of the Settler state" (Paine 1999, 329). They "never willingly ceded their land or political autonomy... [and] hold distinct moral claims as dispossessed first nations" (Short 2005, 272 , italics in original). Turner $(2006,69)$ explains that Aboriginal sovereignty is a "normative political concept for several overlapping reason[s]: Aboriginal people assert it, constitutions recognize it, comprehensive and specific land claims are negotiated because of it, and public policies have been designed and implemented to undermine it." Multiculturalism is one example of a public policy that has served to undermine Aboriginal sovereignty.

Undermining Aboriginal sovereignty occurs through a number of processes and practices. Multiculturalism helps to erase, diminish, trivialize, and deflect from acknowledging Aboriginal sovereignty and the need to redress Aboriginal rights (Légaré 1995; Mackey 2005; Short 2005). Multiculturalism is dependent "upon the deep structures of colonial discourse" (Day and Sadik 2002, 6). These deep structures of colonial discourse are overlapping and intersecting but include historical, political, educational thought, and practice. Although Aboriginal people insist that an understanding of historical relationships is key to understanding Aboriginal sovereignty, normative Canadian history refuses to recognize Aboriginal interpretations of history (Turner 2006); this refusal in turn places limits in understanding Aboriginal sovereignty.

History limits understanding of Aboriginal sovereignty by "rarely discuss[ing] the history of colonial relations, specifically the continual dispossession and marginalization of Aboriginal peoples" (Mackey 2005, 19). Even in recent gestures toward "truth and reconciliation," the innocence of the colonizing governments is defended. At the 2009 G20 meetings, Prime Minister Stephan Harper stated that Canada has "no history of colonialism" 
(Ljunggren 2009). This public denial of the colonization of Aboriginal people can surely be reassuring to a very select group of people. Particularly to those invested in dominant Canadian historical narratives that continue to "efface the history of ill-treatment that Aboriginal peoples have endured at the hands of the Canadian state" (Day and Sadik 2002, 14-15). Histories of racism and the brutal colonization of Aboriginal peoples are routinely ignored, minimized, and erased (Day and Sadik 2002; Mackey 2002; Lawrence and Dua 2005; Montgomery 2005). This minimizing and erasure of brutal colonization has profound detrimental effects for Aboriginal people.

Multiculturalism works against Aboriginal sovereignty and anti-colonialism in its production of national histories that imagine Canada as a socially just and successful multicultural state. Normative Canadian history produces Canada as a nation that is "tolerant" and "innocent." As Francis $(1997,75)$ argued, "the myth of the master race" is a production of Canadian history as benign, serving to promote the belief that "colonists were the innocent victims of Indian aggression" and reassurance that despite brutal colonization "no colonist ever killed an Indian who wasn't asking for it." Many Canadians take enormous pride in the constructed identity of their nation as one that is innocent of any wrongdoing (Backhouse 1999). Representing Canadians as innocent of wrongdoing constructs them as "tolerant" "victims of multiculturalism" (Mackey 2002, 88, 22). Produced as advocates of fairness and equality, Canadians can feel legitimate in rejecting Aboriginal claims to justice. As Légaré (1995, 359) asserted, through this insistence on innocence and tolerance, Aboriginal people are "constructed as the oppressors of ordinary Canadians." This may explain why a suggestion that native studies become the foundation of a combined course in history and social studies in Canada would be met with a response like "Aboriginal people are not the only people here" because that would for some seem to go far beyond what is required and may even be regarded by some as amounting to injustice.

Aboriginal sovereignty remains an important issue, even though the Canadian state may have come into existence through conquering, having power ceded through treaties or by simply overrunning Aboriginal communities (Turner 2006). Aboriginal critics challenge the legitimacy of the current colonial Canadian government to "recognize" and "negotiate" Aboriginal rights within a multicultural framework. Related to this failure is the Canadian 
government's insistence on "recognition theories," which center the idea of "recognizing" Aboriginal rights, always within the context of a colonial framework, and which thoroughly reject Aboriginal sovereignty (Tully 2000). Recognition theorists assert that minor "adjustments" to democracy and common law are insufficient to addressing demands for Aboriginal sovereignty (Povinelli 1998). From the perspective of Aboriginal politics and education, multiculturalism limits a more comprehensive "understanding of Canada as a colonialist state" and diminishes Aboriginal political and educational concerns with "on-going colonization of Indigenous peoples in the Americas" (Lawrence and Dua 2005, 123). ${ }^{2}$

Multiculturalism can also equate Aboriginal people with racialized minorities and particularly racialized ethnic immigrants. By inaccurately assuming shared commonalities among diverse groups (Dei and Calliste 2000), multiculturalism erases the specific and unique location of Aboriginal peoples as Indigenous to this land by equating them with multicultural and immigrant groups. Aboriginal people adamantly reject this equating of their Aboriginal position with ethnic minorities as a form of colonialism (Curthoys 2000; Short 2005). Whether through anti-racism or multiculturalism, when colonialism in Canada is left unaddressed, racialized ethnic immigrants are too easily positioned as innocent (Lawrence and Dua 2005, 132). This position ignores the ways in which "people of color in settler formations are settlers on stolen lands... and historically may have been complicit with on-going land theft and colonial domination of Aboriginal peoples" (Lawrence and Dua 2005, 132). Aboriginal connection to "on-going land claims" remain a key issue (Paine 1999; Lawrence and Dua 2005), setting them apart from all others, and in this way they occupy a unique place in Canada, whether in regards to white or more recent settler/immigrants. Aboriginal peoples assert the need for nation-to-nation negotiations, and refuse multiculturalism's attempts to reduce them to one of many competing "minority" or "ethnic" groups within the nation.

So far I have argued that Aboriginal peoples reject multiculturalism as an instrument of colonialism. Multiculturalism is dependent on colonial structures because it assumes the legitimacy of the current colonial Canadian government. As multiculturalism ignores ongoing colonialization, the result is a trivializing and erasing of Aboriginal sovereignty. Attempting to equate Aboriginal people 
with racialized minorities, multiculturalism erases the unique Indigenous/Aboriginal location of Aboriginal peoples. The practices of multiculturalism, which I have discussed in this section, rely on discourses of recognition, tolerance, and fairness, and have tremendous power in educational settings. Inasmuch as non-Aboriginal teachers, administrators, and students accept these discourses, these individuals demonstrate resistance, suspicion, and even resentment toward Aboriginal teachers and the knowledge they bring to public schools. The next section addresses the experiences of Aboriginal teachers in public schools and their attempts to integrate Aboriginal content and perspectives.

\section{ABORIGINAL EDUCATION ENCOUNTERS WITH MULTICULTURALISM}

At the onset of this article, I stated that what happens to Aboriginal teachers in Canadian public schools as they attempt to include Aboriginal content and perspectives is a microcosm of what happens at the political and national levels in regard to Aboriginal peoples' claims to land and sovereignty in Canada. Drawing on qualitative data generated from two studies I have conducted, Aboriginal teachers report on their experiences of incorporating Aboriginal content and perspectives into public schools (St. Denis et al. 1998; St. Denis 2010). The national politics of denial, resentment, and dismissal of Indigenous rights and sovereignty is also repeated in public schools and detrimentally impacts the work of Aboriginal teachers.

Multiculturalism has been and is used to defend public schools against the need to respond to Aboriginal education. Historically, the need for respectful and meaningful inclusion of Aboriginal education in public schools has long been identified. For example, the Hawthorne (1967, 143-147) report, a comprehensive study of "Indians" in Canada, acknowledged that white racism against Indians was a very real problem and that the attitudes and outlook of white dominant communities needed to change. Yet in its conclusions, this report states, "society and school accept little responsibility for those who cannot conform and the teacher is not in the position to fight an educational system and a society on behalf of a few children out of the many" (Hawthorne 1967, 121). This idea that schools cannot change on behalf of a few 
Aboriginal children is echoed in the sentiment with which I began this article, that "Aboriginal people are not the only people here" in public schools. Public schools are defended as neutral multicultural spaces where all participants are equally positioned, irrespective of racism and colonialism. In the early 1970s Trudeau defended Canada as a neutral multicultural nation in which there is "no official culture, nor does any ethnic group take precedence over any other" (James 2011, 194). This idea that Canada does not have an official culture is contested (Mackey 2002; James 2011) and the experiences of Aboriginal teachers belie this claim of multicultural neutrality.

Multiculturalism is used as a pretext to justify refusal for an authentic engagement with Aboriginal people, culture, and history. Citing public schools as multicultural spaces permits and enables the expression of "veiled" resentment and resistance to the inclusion of Aboriginal people, culture, and history into public school curricula. The statement, "Aboriginal people are not the only people here" aptly communicates this resentment. Aboriginal teachers in public schools often encounter the discounting of Aboriginal content and perspectives in favor of "existing multicultural curriculum" (St. Denis 2010, 35). Non-Aboriginal colleagues assume the upper "moral" ground, insisting, "with multiculturalism, we can't only focus on one culture" (St. Denis 2010, 35). Multiculturalism in schools suggests that Aboriginal content and perspectives are to be regarded as merely one perspective among many.

Multiculturalism diminishes the importance and need for Aboriginal content and perspectives, just as it facilitates the diminishing of the sovereignty claims of Aboriginal people. As an Aboriginal teacher explained, resistance to Aboriginal content is justified on the basis that "there are other children here" (St. Denis et al. 1998, 65). Permitting expressions of resentment and resistance, non-Aboriginal colleagues are confident that they can "question the focus on Aboriginal content" (St. Denis et al. 1998, 41) and imply that the presence of Aboriginal teachers is an "intrusion" (St. Denis 2010, 41; St. Denis et al. 1998, 64). Public schools are defended as multicultural spaces, notwithstanding criticism of multiculturalism as inadequate to address racism (Vanhouwe 2007; James 2011) and ongoing colonialism. Multiculturalism in schools makes it possible for non-Aboriginal teachers and schools to trivialize Aboriginal content and perspectives, and at the same time believe that they are becoming more inclusive and respectful. 
Aboriginal teachers explain that their non-Aboriginal colleagues need a more meaningful understanding of what it means to incorporate Aboriginal content and perspectives. As one teacher stated, "When non-Aboriginal teachers ask us to deal with Aboriginal issues, they expected us to make bannock...they don't really understand how to make it meaningful"' (St. Denis 2010, 36). The folklorization of multiculturalism and culture results in public schools not only trivializing Aboriginal content and perspectives, but also conflating multiculturalism with Aboriginal education (Légare 1995). This means that there is a very narrow space left for including Aboriginal education, and particularly for understanding what Aboriginal content might be included and how.

For example, one Aboriginal teacher explained that "A little content is allowed, nothing substantial, instead of counting sticks, they count buffalo and call that Aboriginal education" (St. Denis et al. 1998, 65). Aboriginal teachers emphasize that teaching about Aboriginal culture and history must go beyond cultural artifacts: "We need the perspective, not just beads and feathers" (St. Denis 2010, 36). As they communicated over and over again, "we don't sit back in our teepees and bead forever, there is only so much beading we can do" (St. Denis et al. 1998, 65). Multiculturalism allows schools to assume Aboriginal people, history, and culture are available as mere sources of "enrichment" (Mackey 2002, 98, quoting Hage 1994).

Aboriginal teachers recognize the need for meaningful Aboriginal content and perspectives that address the ways in which racism and colonialism shape the lives of Aboriginal people in Canada. As Aboriginal teachers explain, their non-Aboriginal colleagues are often not open to addressing these issues and "don't want us to make that real" (St. Denis 2010, 36). Aboriginal teachers explain, "people don't want you broaching topics closer to the heart. They only want to talk about fluff" (St. Denis 2010, 35). Part of "making it real" and getting away from "fluff" would involve providing curricular content and teaching practice that exposes the ways in which Aboriginal people have been dehumanized in Canada (Dion 2007). This may involve non-Aboriginal teachers honestly acknowledging the ways in which Canada has oppressed Aboriginal people in the past, and how Canadian legal institutions continue to dismiss their demands for justice and claims to Aboriginal sovereignty. A defense of schools as multicultural, and the suggestion that attention to historical and ongoing forms of 
colonialism will result in injustice for non-Aboriginals in the public classroom act as significant barriers to anti-colonialism and anti-racism.

Throughout this article, I have made the argument that what happens to Aboriginal teachers and Aboriginal content in Canadian public schools is a microcosm of what happens at the political level in regards to Aboriginal people. The prevailing and prevalent policy and practice of multiculturalism enables a refusal to address ongoing colonialism, and even to acknowledge colonialism at all. This leads to the trivializing of issues, to attempts to collapse Aboriginal rights into ethnic and minority issues, and to forcing Aboriginal content into multicultural frameworks. All of these practices deny the reality of Canadian colonialism and reduce efforts for Aboriginal sovereignty and education. The experiences of Aboriginal teachers teach us that just as the Canadian national space is not neutral, so are school spaces not neutral. Dominant cultures regard efforts to address inequality and diversity as a rejection of, and even an intrusion into, broad understandings of self and nation, and so they therefore resist and resent Aboriginal knowledges and history.

Ahmed (2007/2008, 127) has argued that multiculturalism encourages a politics of happiness, whereby those who encounter multiculturalism as racism in disguise or another form of colonialism are socially pressured into silence in order to "maintain signs of getting along"; otherwise, they risk being positioned as the "killjoy." Silencing and further oppression is achieved by suggesting that the "exposure of violence becomes the origins of violence" (Ahmed 2007/2008, 127). Resistance to making Aboriginal content and perspectives in schools "real" is similarly positioned when there is pressure being applied to avoid teaching "difficult knowledge" so that the image of Canada as a fair and just country can be preserved.

Aboriginal teachers are adamant that they are not going away and neither are Aboriginal people. As one Aboriginal teacher stated, "We are not going anywhere. We are still here. And 500 hundred years from now, we will still be here" (St. Denis 2010, 40). If we want success for Aboriginal students in public schools, perhaps our schools and educational institutions must be committed to challenging the Canadian fantasy expressed by Harper, when he made the statement that Canada does not have a history of colonialism. We must start with acknowledging both the past and continuing 
injustice toward Aboriginal people rather than evading and erasing, so we can become a country committed to justice and fairness.

\section{NOTES}

1. I draw on Augie Fleras and Jean Leonard Elliott's (1992) book, Multiculturalism in Canada: The Challenge of Diversity, as a source for basic information on multiculturalism in Canada.

2. Lawrence and Dua are primarily critiquing anti-racism education as failing to recognize colonialism and Indigeneity, but they also do a critique of multiculturalism.

\section{REFERENCES}

Ahmed, S. (2007/2008). Multiculturalism and the Promise of Happiness. New Formations, 63, 121-137.

Backhouse, C. (1999). Colour-Coded: A Legal History of Racism in Canada, 1900-1950. Toronto, Canada: University of Toronto Press.

Chakrabarty, D. (2001). Reconciliation and its Historiography: Some Preliminary Thoughts. UTS Review, 7(4), 6-16.

Curthoys, A. (2000). An Uneasy Conversation: The Indigenous and the Multicultural. In J. Docker \& G. Fischer (Eds.), Colour and Identity in Australia and New Zealand (pp. 21-36). Sydney, Australia: UNSW Press 2000.

Day, R. J. F. (2000). Multiculturalism and the History of Canadian Diversity. Toronto, Canada: University of Toronto Press.

Day, R. J. F. and Sadik, T. (2002). The BC Land Question, Liberal Multiculturalism, and the Spectre of Aboriginal Nationhood. BC Studies, 134, 5-34.

Dei, G. J. S. and Calliste, A. (2000). Mapping the Terrain: Power, Knowledge and Anti-Racism Education. In G. J. S. Dei \& A. Calliste (Eds.), Power, Knowledge and Anti-Racist Education (pp. 11-22). Halifax, Canada: Fernwood Publishing 2000.

Dion, S. (2007). Disrupting Molded Images: Identities, Responsibilities and Relationships-Teachers and Indigenous Subject Material. Teaching Education, 18(4), 329-342.

Fleras, A. and Elliot, J. E. (1992). Multiculturalism in Canada: The Challenge of Diversity. Scarborough, Canada: Nelson Canada.

Francis, D. (1997). National Dreams: Myth, Memory and Canadian History. Vancouver, Canada: Arsenal Pulp Press.

Hage, G. (1994). Locating Multiculturalism's Other: A Critique of Practical Tolerance. New Formations, 24, 21-32, quoted in Mackey (2002), 98.

Hawthorne, H. B. (1967). A Survey of the Contemporary Indians of Canada: Economic, Political, Educational Needs and Policies, Vol. 1 and 2. Ottawa, Canada: Indian Affairs Branch.

James, C. E. (2011). Multicultural Education in a Color-Blind Society. In C. A. Grant \& A. Portera (Eds.), Intercultural and Multicultural Education: Enhancing Global Interconnectedness (pp. 191-210). New York: Routledge. 
Kymlicka, W. (1996). Multicultural Citizenship: A Liberal Theory of Minority Rights. Oxford, England: Clarendon Press.

Lawrence, B. and Dua, E. (2005). Decolonizing Antiracism. Social Justice, 32(4), 120-143.

Légaré, E. I. (1995). Canadian Multiculturalism and Aboriginal People: Negotiating a Place in the Nation. Identities, 1, 347-366.

Ljunggren, D. (2009). Every G20 nation wants to be Canada, insists PM. Reuters September 25. http://www.reuters.com/article/2009/09/26/columns-us-g20canada-advantages-idUSTRE58P05Z20090926

Mackey, E. (2002). The House of Difference: Cultural Politics and National Identity in Canada. Toronto, Canada: University of Toronto Press.

Mackey, E. (2005). Universal Rights in Conflict: 'Backlash' and 'Benevolent Resistance' to Indigenous Land Rights. Anthropology Today, 21(2), 14-20.

Montgomery, K. (2005). Imagining the Anti-Racist State: Representations of Racism in Canadian History Textbooks. Discourse Studies in the Cultural Politics of Education, 25, 427-442.

Paine, R. (1999). Aboriginality, Multiculturalism, and Liberal Rights Philosophy. Ethnos, 64, 325-349.

Povinelli, E. (1998). The State of Shame: Australian Multiculturalism and the Crisis of Indigenous Citizenship. Critical Inquiry, 24, 575-610.

Rutherford, S. (2010). Colonialism and the Indigenous Present: An Interview with Bonita Lawrence. Race \& Class, 52(1), 9-18.

Short, D. (2005). Reconciliation and the Problem of Internal Colonialism. Journal of Intercultural Studies, 26, 267-282.

St. Denis, V. (2010, March 10.). A Study of Aboriginal Teachers' Professional Knowledge and Experience in Canadian Public Schools. Ottawa, Canada: Canadian Teachers' Federation and Canadian Council on Learning.

St. Denis, V., Bouvier, R., and Battiste, M. (1998). Okiskinahamakewak-Aboriginal Teachers in Saskatchewan's Publicly Funded Schools: Responding to the Flux. Final Report, October 31. Regina, Canada: Saskatchewan Education Research Networking Project.

Tully, J. (2000). The Struggles of Indigenous Peoples for and of Freedom. In D. Ivison, P. Patton \& W. Sanders (Eds.), Political Theory and the Rights of Indigenous Peoples (pp. 36-59). Cambridge, England: Cambridge University Press.

Turner, D. (2006). This is not a peace pipe: Towards a critical Indigenous philosophy. London: University of Toronto Press.

Vanhouwe, M. I. (2007). White Teachers, Critical Race Theory and Aboriginal Education. Masters Thesis, University of Saskatchewan, Saskatoon, Canada.

Wood, P. and Gilbert, L. (2005). Multiculturalism in Canada: Accidental Discourse, Alternative Vision, Urban Practice. International Journal of Urban and Regional Research, 29, 679-691. 